\title{
Larval infestation of chronic ischaemic leg ulcer
}

\author{
Walid Ibrahim, Lubna Osman, Ahmed Subahi
}

Internal Medicine, Wayne State University, Detroit, Michigan, USA

\section{Correspondence to}

Dr Walid Ibrahim,

wibrahim@med.wayne.edu

Accepted 18 December 2017

\section{DESCRIPTION}

Several cases of obligatory wound myiasis have been reported in the medical literature. ${ }^{1-3}$ For a long time, such infestation was perceived as a complication of poor quality wound care in patients with chronic ulcers. There are only three cases of wound myiasis reported in the literature. Demirel et al reported on a 68-year-old male patient with larvae infestations of diabetic wound that were discovered during surgical debridement. ${ }^{3}$ Another two cases of traumatic larval infestation associated with Bowen carcinoma and with chronic leg ulcer were reported. ${ }^{3}$ Up to date, there is no report of chronic ulcer with massive larvae infestation as in this patient.

Figure 1 with video capture (video 1) demonstrates a massive larvae infestation of severe chronic ischaemic ulcer in a 60-year-old homeless male patient with HIV, who presented with unilateral leg pain without systemic or local signs of infection. The local examination of the ulcer site demonstrates a significant diamond-shaped ulcer 4.7 inch $\times 2.3$ inches exposing the Achilles tendon and the surrounding granulation tissue with no evidence of local signs of infections.

Management of chronic wound ulcer is usually prolonged and challenging. Therefore, different approaches have been implemented in wound management, including what is called maggot debridement therapy (MDT). MDT can improve debridement, disinfection, bacterial biofilm eradication, and ultimately wound healing. ${ }^{4}$ Consequently, therapeutic maggot debridement has been approved as a novel modality of ulcer treatment. ${ }^{5}$ Our patient's circumstances of poor hygiene, homeless situation and severe peripheral vascular disease drastically increased his risk of repeated wound infection. However, the presence of the associated larvae infestation appears to help natural wound debridement and prevent bacterial infection.

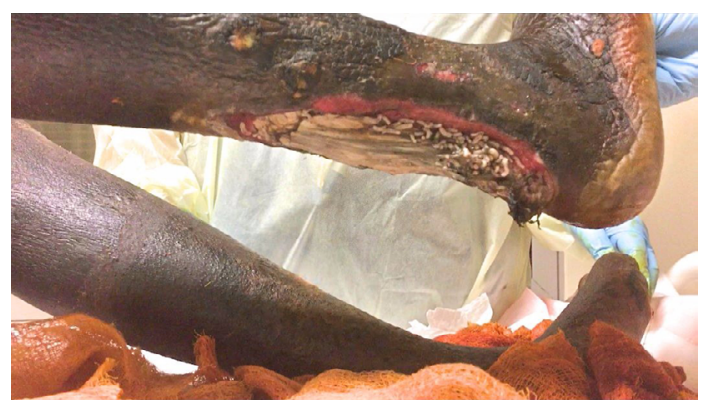

Figure 1 Myiasis infestation of chronic ulcer.

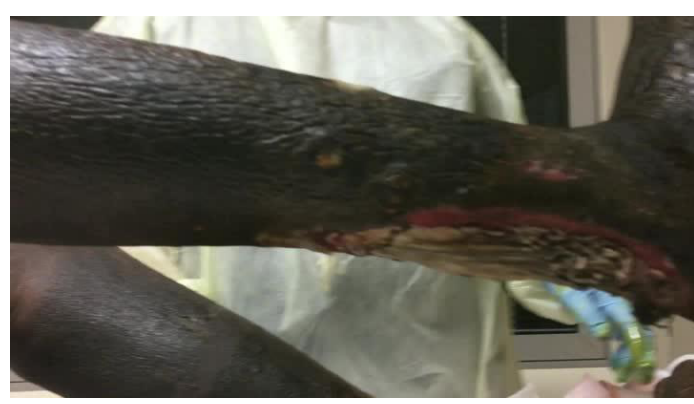

Video 1 Myiasis infestation of chronic ulcer.

\section{Learning points}

Management of chronic ulcer is challenging; multidisciplinary approaches seem to be effective in treating and preventing chronic ulcer of all types.

- Biotherapy of ulcer with maggots is a reintroduced modality in treatment, which has been approved by the Food and Drug Administration in 2004 for that purpose.

- Coinfection with maggots my play a significant counteractor role in preventing superadded bacterial infection.

Contributors WI: provided the discussion and the idea. LO: provided the learning points: AS: conducted the literature review, provided the pictures and prepared the video.

Competing interests None declared.

Patient consent Obtained.

Provenance and peer review Not commissioned; externally peer reviewed.

(C) BMJ Publishing Group Ltd (unless otherwise stated in the text of the article) 2018. All rights reserved. No commercial use is permitted unless otherwise expressly granted.

\section{REFERENCES}

1 Lam KH, Lui TH. Myiasis of the foot and leg caused by chrysomya bezziana. J Foot Ankle Surg 2014;53:88-91.

2 Sherman RA. Maggot therapy takes us back to the future of wound care: new and improved maggot therapy for the 21st century. J Diabetes Sci Technol 2009;3:336-44.

3 Demirel Kaya F, Orkun 0, Cakmak A, et al. [Cutanous myiasis caused by sarcophaga spp. larvae in a diabetic patient]. Mikrobiyol Bul 2014;48:356-61.

4 Anegg B, Auer $H$, Diem E, et al. [Wound myiasis. facultative myiasis]. Hautarzt 1990;41:461-3.

5 Davydov L. Maggot therapy in wound management in modern era and a review of published literature. J Pharm Pract 2011;24:89-93. 
Copyright 2017 BMJ Publishing Group. All rights reserved. For permission to reuse any of this content visit http://group.bmj.com/group/rights-licensing/permissions.

BMJ Case Report Fellows may re-use this article for personal use and teaching without any further permission.

Become a Fellow of BMJ Case Reports today and you can:

- Submit as many cases as you like

- Enjoy fast sympathetic peer review and rapid publication of accepted articles

Access all the published articles

- Re-use any of the published material for personal use and teaching without further permission

For information on Institutional Fellowships contact consortiasales@bmjgroup.com

Visit casereports.bmj.com for more articles like this and to become a Fellow 